\title{
Faktor-Faktor yang Berhubungan dengan Perilaku Perilaku Penggunaan Alat Pelindung Diri oleh Bidan pada Persalinan Normal di Kota Tanjungbalai Tahun 2020
}

\author{
Evi Erianty Hasibuan
}

Program Studi Kebidanan, Institut Teknologi dan Kesehatan Sumatera Utara

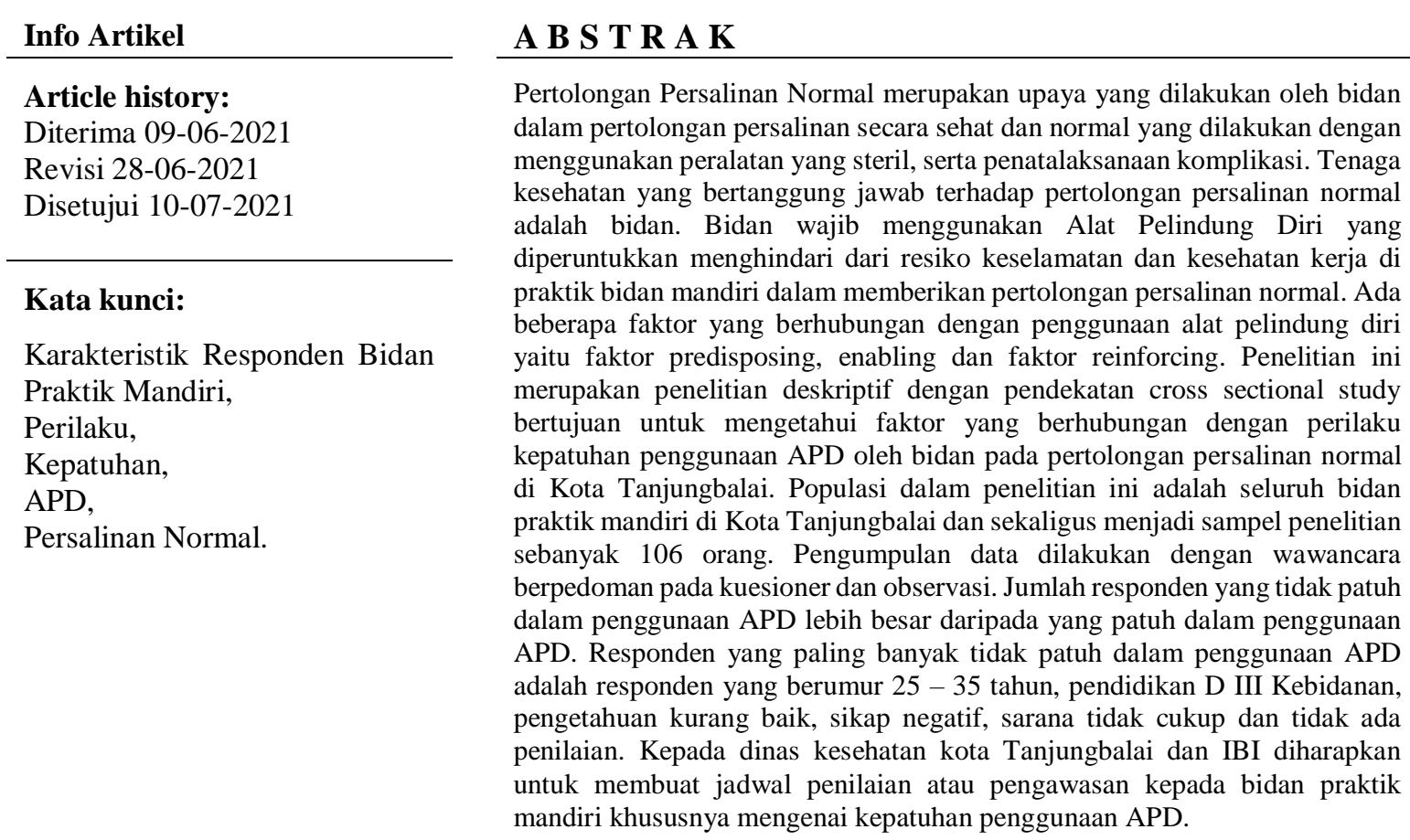

\section{Koresponden Penulis:}

Evi Erianty Hasibuan,

Program Studi Keperawatan, Institut Teknologi dan Kesehatan Sumatera Utara,

Jl. Trans Sumatera Bukittinggi - Padang Sidempuan, Sihitang, Padangsidimpuan Tenggara, Kota Padang

Sidempuan, Sumatera Utara 22733.

Email: evi.akhmad@gmail.com

\section{PENDAHULUAN}

Kesehatan merupakan hak asasi manusia dan salah satu unsur kesejahteraan yang harus diwujudkan sesuai dengan cita-cita bangsa Indonesia sebagaimana dimaksud dalam Pancasila dan Undang-Undang Dasar Negara Republik Indonesia 1945. Pekerja yang sehat adalah faktor penentu yang vital untuk pertumbuhan sosial ekonomi yang berkesinambungan, sehingga di era globalisasi ini menuntut pelaksanaan Kesehatan dan Keselamatan Kerja (K3) disetiap tempat kerja termasuk di sektor kesehatan dalam rangka menekan serendah mungkin resiko kecelakaan dan penyakit yang timbul akibat hubungan kerja, serta meningkatkan produktivitas dan efisiensi. Dalam pelaksanaan pekerja sehari-hari karyawan/pekerja di sektor kesehatan akan terpajan dengan resiko bahaya di tempat kerja. Resiko ini bervariasi mulai dari yang paling ringan sampai yang paling berat tergantung jenis pekerjaannya (Kurniawidjaya, 2010).

Masalah keselamatan dan kesehatan kerja adalah masalah dunia. Telah banyak diketahui bahwa bekerja dimanapun selalu ada resiko terkena Penyakit Akibat Kerja (PAK). Baik bekerja di 
darat, laut, udara, bawah tanah, maupun dirgantara: bekerja di sektor jasa, industri, pertanian, kehutanan, kesehatan, transportasi, laboratorium, rumah sakit, atau tempat lainnya. PAK tidak hanya terjadi di negara berkembang tetapi juga di negara maju (Kurniawidjaya, 2010).

Menurut WHO (2015) menyatakan penyakit umum pada pekerja dapat berupa penyakit infeksi dan penyakit noninfeksi. Tenaga medis merupakan profesi yang beresiko terinfeksi virus dari pasien. Angka kejadian tenaga kesehatan yang tertular Hepatitis B dan C serta HIV yang ditularkan oleh pasien cenderung tinggi. Penularan ini dapat terjadi melalui kulit yang terluka oleh jarum, pisau, dan benda tajam lain atau paparan selaput lendir dengan cairan tubuh. Salah satu tenaga kerja sektor formal ynag berpotensi terhadap keadaan kesehatan kerjanya adalah bidan di rumah sakit. Menurut WHO Bidan adalah seseorang yang telah diakui secara reguler dalam program pendidikan kebidanan sebagaimana yang diakui yuridis, dimana ia ditempatkan dan telah menyelesaikan pendidikan kebidanan dan telah mendapatkan kualifikasi serta terdaftar disahkan dan mendapatkan ijin melaksanakan praktik kebidanan( WHO, 2014 ).

Bidan diharuskan memberikan pelayanan kebidanan yang kontinyu (Continuity of Care) mulai dari Ante Natal Care (ANC), Intra Natal Care (ANC), Asuhan Bayi Baru Lahir (BBL), Asuhan Postpartum, Asuhan Neonatus dan Pelayanan KB yang berkualitas. Pencapaian sasaran MDGs pada tahun 2015 menjadi salah satu prioritas utama bangsa Indonesia. Pencapaian tujuan dan target tersebut bukanlah semata-mata tugas pemerintah tetapi merupakan tugas seluruh komponen bangsa. Sehingga pencapaian tujuan dan target MDGs harus menjadi pembahasan seluruh masyarakat, termasuk Ikatan Bidan Indonesia (IBI). IBI dan anggota IBI telah mengambil peran dalam menyukseskan pencapaian target MDGs, khususnya target 4 dan 5 yang merupakan area pelayanan Kebidanan, Kesehatan Ibu dan Anak (KIA) dan Keluarga Berencana (KB) (IBI, 2015).

Mekanisme pelaksanaan Asuhan Persalinan Normal (APN) tidak terlepas dari penggunaan alat kesehatan yang berpotensi terhadap gangguan kesehatan bidan. Salah satu cara upaya pencegahan gangguan kesehatan akibat kerja adalah penggunaan Alat Pelindung Diri (APD) (Sari, 2017). APD yaitu alat kerja terpisah yang digunakan untuk melindungi sebagian atau seluruh dari potensi bahaya atau penyakit akibat kerja. Wieke (2016) menyatakan APD adalah alat yang memiliki kekuatan melindungi pekerja dari bahaya di tempat kerja. Pemakaian APD ditujukan untuk membuat perlindungan atau mengisolasi pekerja dari hazard kimia atau fisik dan biologi yang mungkin didapati. APD harus memenuhi syarat-syarat yakni enak digunakan, tak menggangu kerja, dan memberi perlindungan yang efisien pada jenis bahaya. (Wordpres, 2017).

Survei yang dilakukan pada bidan di Amerika selama enam bulan menunjukkan bahwa 74\% bidan pernah menyentuh darah pasien dengan tangan telanjang, $51 \%$ pernah mengami percikan darah atau cairan tubuh di wajah, 24\% mengalami pajanan jarum suntik, dan hanya 55\% bidan yang memiliki perilaku kesehatan dan keselamatan kerja yang baik. Hasil penelitian Burke dan Madan di Inggris pada tahun 1997 menyimpulkan bahwa dari 293 bidan sebanyak 63 orang bidan mengalami kecelakaan kerja selama semester kedua tahun 1996, dan hanya 29 diantara mereka yang melaporkannya ke Departemen Kesehatan Inggris. Para bidan tidak melaporkan kecelakaan kerja yang mereka alami karena hanya membuang buang waktu (Soni, 2016). Berdasarkan survey singkat yang dilakukan peneliti terkait kepatuhan penggunaan APD di Kota Tanjungbalai terhadap 20 bidan yang ada di Kota Tanjungbalai didapatkan 20 bidan tersebut tidak pernah menggunakan penutup kepala, masker, kacamata, dan sepatu bot. Sementara itu didapatkan 5 orang bidan menggunakan sarung tangan dan celemek, dan 15 orang bidan hanya menggunakan sarung tangan. Hal ini dikarenakan berbagai alasan diantaranya kurangnya pengetahuan dan tidak memahami sepenuhnya pentingnya penggunaan APD yang lengkap dan sesuai standar pelayanan persalinan normal.

\section{METODE PENELITIAN}

Penelitian ini bersifat observasional analitik dengan menggunakan studi cross sectional untuk mengetahui faktor yang berhubungan dengan perilaku kepatuhan penggunaan APD pada pertolongan persalinan normal di Kota Tanjungbalai tahun 2020.

Penelitian dilakukan di Kota Tanjungbalai. Penelitian dimulai dengan penelusuran daftar pustaka, survey awal, persiapan proposal penelitian, pelaksanaan penelitian, sampai penyusunan laporan akhir. Penelitian ini berlangsung selama Januari 2020 - Mei 2020.

Faktor-Faktor yang Berhubungan dengan Perilaku Perilaku Penggunaan Alat ... ( Evi Erianty Hasibuan) 
Dalam penelitian ini metode analisa yaitu analisa univariat, analisa bivariat (menggunakan uji chi-square test), dan analisa multivariate (menggunakan regresi logistic).

\section{HASIL DAN PEMBAHASAN}

3.1. Hasil

A. Analisa Univariat

Tabel 1. Distribusi Frekuensi Karakteristik Responden Bidan Praktik Mandiri di Kota Tanjungbalai Tahun

\begin{tabular}{|c|c|c|}
\hline Karakteristik & Frekuensi & Proporsi \\
\hline $\begin{array}{l}\text { Umur } \\
25-35 \text { Tahun } \\
36-55 \text { Tahun }\end{array}$ & $\begin{array}{l}62 \\
44\end{array}$ & $\begin{array}{l}58,5 \\
41,5\end{array}$ \\
\hline $\begin{array}{l}\text { Pendidikan } \\
\text { D III Kebidanan } \\
\text { D IV Kebidanan }\end{array}$ & $\begin{array}{l}68 \\
38\end{array}$ & $\begin{array}{l}64,2 \\
35,8\end{array}$ \\
\hline $\begin{array}{l}\text { Pengetahuan } \\
\text { Kurang baik } \\
\text { Baik }\end{array}$ & $\begin{array}{l}62 \\
44\end{array}$ & $\begin{array}{l}58,5 \\
41,5\end{array}$ \\
\hline $\begin{array}{l}\text { Sikap } \\
\text { Negatif } \\
\text { Positif }\end{array}$ & $\begin{array}{l}62 \\
44\end{array}$ & $\begin{array}{l}58,5 \\
41,5\end{array}$ \\
\hline
\end{tabular}

Berdasarkan tabel di atas dapat dilihat bahwa distribusi responden berdasarkan umur 25 - 35 tahun sebanyak 62 orang $(58,5 \%)$, pada rentang umur $36-55$ tahun sebanyak 44 orang $(41,5 \%)$. Berdasarkan pendidikan D III Kebidanan sebanyak 68 orang ( 64,5 \%), pendidikan D IV Kebidanan sebanyak 38 orang ( $35,8 \%$ ). Berdasarkan pengetahuan kurang baik sebanyak 62 orang $(58,5 \%)$, pengetahuan baik sebanyak 44 orang $(41,5 \%)$. Berdasarkan sikap negatif sebanyak 62 orang $(58,5 \%)$, dan sikap positif 44 orang $(41,5 \%)$.

Tabel 2. Distribusi Frekuensi Bidan Berdasarkan Sarana Di Kota Tanjungbalai Tahun 2020

\begin{tabular}{ccc}
\hline Sarana & Frekuensi & Proporsi \\
\hline Tidak cukup & 62 & 58,5 \\
Cukup & 44 & 41,5 \\
\hline Total & 106 & 100 \\
\hline
\end{tabular}

Berdasarkan tabel diatas dapat diketahui bahwa distribusi frekuensi terbesar adalah responden memiliki sarana tidak cukup yaitu sebanyak 62 orang $(58,5 \%)$.

Tabel 3. Distribusi Frekuensi Bidan Berdasarkan Penilaian Di Kota Tanjungbalai Tahun 2020

\begin{tabular}{ccc}
\hline Penilaian & Frekuensi & Proporsi \\
\hline Ada & 48 & 45,3 \\
Tidak ada & 58 & 54,7 \\
\hline Total & 106 & 100
\end{tabular}

Berdasarkan tabel diatas dapat diketahui bahwa distribusi frekuensi terbesar adalah responden yang tidak ada penilaian yaitu sebanyak 58 orang $(54,7 \%)$.

Tabel 4. Distribusi Frekuensi Bidan Berdasarkan Kepatuhan Penggunaan APD Di Kota Tanjungbalai Tahun 2020

\begin{tabular}{ccc}
\hline Penggunaan APD & Frekuensi & Proporsi \\
\hline Patuh & 51 & 48,1 \\
Tidak patuh & 55 & 51,9 \\
\hline Total & 106 & 100 \\
\hline
\end{tabular}

\section{B. Analisa Bivariat}

Tabel 5. Hubungan Umur Dengan Kepatuhan Penggunaan APD Oleh Bidan Pada Pertolongan Persalinan Normal Di Kota Tanjungbalai Tahun 2020 


\begin{tabular}{|c|c|c|c|c|c|c|c|c|}
\hline \multirow{3}{*}{ Umur } & \multicolumn{4}{|c|}{$\begin{array}{c}\text { Kepatuhan } \\
\text { Penggunaan APD }\end{array}$} & \multirow{2}{*}{\multicolumn{2}{|c|}{$\begin{array}{c}\text { Total } \\
\text { Proporsi }\end{array}$}} & \multirow{3}{*}{$\begin{array}{c}\mathbf{P} \\
\text { value }\end{array}$} & \multirow{3}{*}{ RP ( $95 \%$ CI $)$} \\
\hline & \multicolumn{2}{|c|}{$\begin{array}{l}\text { Tidak } \\
\text { Patuh }\end{array}$} & \multicolumn{2}{|c|}{ Patuh } & & & & \\
\hline & $\mathbf{n}$ & $\%$ & $\mathbf{n}$ & $\%$ & $\mathbf{n}$ & $\%$ & & \\
\hline $25-35$ & 34 & 54,8 & 28 & 45,2 & 62 & 100 & 076 & 1,005 \\
\hline $36-55$ & 24 & 54,5 & 20 & 45,5 & 44 & 100 & 0,910 & \\
\hline
\end{tabular}

Berdasarkan analisis statistik dengan menggunakan chi - square diketahui nilai $p>0,05$ artinya tidak ada hubungan antara umur dengan ketidak patuhan bidan praktik mandiri dalam penggunaan APD pada pertolongan persalinan normal.

Tabel 6. Hubungan Pendidikan Dengan Kepatuhan Penggunaan APD Oleh Bidan Pada Pertolongan Persalinan Normal Di Kota Tanjungbalai Tahun 2020

\begin{tabular}{|c|c|c|c|c|c|c|c|c|}
\hline \multirow{3}{*}{$\begin{array}{l}\text { Pendidi } \\
\text { kan }\end{array}$} & \multicolumn{4}{|c|}{$\begin{array}{c}\text { Kepatuhan } \\
\text { penggunaan APD }\end{array}$} & \multirow{2}{*}{\multicolumn{2}{|c|}{$\begin{array}{c}\text { Total } \\
\text { proporsi }\end{array}$}} & \multirow{3}{*}{$\begin{array}{c}\mathbf{p} \\
\text { value }\end{array}$} & \multirow{3}{*}{$\begin{array}{c}\text { RP } \\
(95 \% \mathrm{CI})\end{array}$} \\
\hline & \multicolumn{2}{|c|}{$\begin{array}{l}\text { Tidak } \\
\text { Patuh }\end{array}$} & \multicolumn{2}{|c|}{ Patuh } & & & & \\
\hline & $\mathbf{n}$ & $\%$ & $\mathbf{n}$ & $\%$ & $\mathbf{n}$ & $\%$ & & \\
\hline D III & & & 2 & & & & & \\
\hline $\begin{array}{l}\text { Kebidan } \\
\text { an }\end{array}$ & 44 & 64,7 & 4 & 35,3 & 68 & 100 & 0,010 & 1,756 \\
\hline $\begin{array}{l}\text { D IV } \\
\text { Kebidan } \\
\text { an }\end{array}$ & 14 & 36,8 & $\begin{array}{l}2 \\
4\end{array}$ & 63,2 & 38 & 100 & & $(1,118-2,759)$ \\
\hline
\end{tabular}

Berdasarkan analisis statistik dengan menggunakan chi - square diketahui nilai $p<0,05$ artinya ada hubungan antara pendidikan dengan ketidak patuhan bidan praktik mandiri dalam penggunaan APD pada pertolongan persalinan normal. Dengan nilai RP sebesar 1,756 (95\% CI =1,118-2,759) maka dapat disimpulkan bahwa bidan praktik mandiri yang memiliki pendidikan D III Kebidanan 1,75 kali perkiraan resiko tidak patuh dalam penggunaan APD pada pertolongan persalinan normal.

Tabel 7. Hubungan Pengetahuan Dengan Kepatuhan Penggunaan APD Oleh Bidan Pada Pertolongan Persalinan Normal Di Kota Tanjungbalai Tahun 2020

\begin{tabular}{|c|c|c|c|c|c|c|c|c|}
\hline \multirow{3}{*}{$\begin{array}{l}\text { Penget } \\
\text { ahuan }\end{array}$} & \multicolumn{5}{|c|}{ Kepatuhan penggunaan APD } & \multirow{3}{*}{$\begin{array}{c}\text { Total } \\
\text { Propor } \\
\text { si } \\
\%\end{array}$} & \multirow{3}{*}{$p$ value } & \multirow{3}{*}{$\mathbf{R P}(95 \% \mathrm{CI})$} \\
\hline & \multicolumn{2}{|c|}{$\begin{array}{l}\text { Tidak } \\
\text { Patuh }\end{array}$} & \multicolumn{3}{|c|}{ Patuh } & & & \\
\hline & $\mathbf{n}$ & $\%$ & $\mathbf{n}$ & $\%$ & $\mathbf{n}$ & & & \\
\hline Kurang & 41 & 661 & 21 & 339 & 62 & 100 & & 1712 \\
\hline $\begin{array}{l}\text { Baik } \\
\text { Baik }\end{array}$ & 17 & 38,6 & 27 & 61,4 & 44 & 100 & 0,009 & $(1,133-2,586)$ \\
\hline
\end{tabular}

Berdasarkan analisis statistik dengan menggunakan chi - square diketahui nilai $p<0,05$ artinya ada hubungan antara pengetahuan dengan ketidak patuhan bidan praktik mandiri dalam penggunaan APD pada pertolongan persalinan normal. Dengan nilai RP sebesar 1,712 $(95 \% \mathrm{CI}=1,133-2,586$ ) maka dapat disimpulkan bahwa bidan praktik mandiri yang memiliki pengetahuan kurang baik 1,71 kali perkiraan resiko tidak patuh dalam penggunaan APD pada pertolongan persalinan normal.

Tabel 8. Hubungan Sikap Dengan Kepatuhan Penggunaan APD Oleh Bidan Pada Pertolongan Persalinan Normal Di Kota Tanjungbalai Tahun 201

\begin{tabular}{|c|c|c|c|c|c|c|c|c|}
\hline \multirow{4}{*}{ Sikap } & \multicolumn{4}{|c|}{ Kepatuhan penggunaan } & \multirow{2}{*}{\multicolumn{2}{|c|}{ Total }} & \multirow{4}{*}{$\begin{array}{c}\mathbf{p} \\
\text { value }\end{array}$} & \multirow[b]{3}{*}{ RP ( $95 \%$ CI $)$} \\
\hline & & & & & & & & \\
\hline & \multicolumn{2}{|c|}{$\begin{array}{l}\text { Tidak } \\
\text { Patuh }\end{array}$} & \multicolumn{2}{|c|}{ Patuh } & & orsi & & \\
\hline & $\mathbf{n}$ & $\%$ & $\mathbf{n}$ & $\%$ & $\mathbf{n}$ & $\%$ & & \\
\hline Negatif & 40 & 64,5 & 22 & 35,5 & 62 & 100 & 07 & 1,577 \\
\hline Positif & 18 & 40,9 & 26 & 59,1 & 44 & 100 & 0,021 & $(1,057-2,353)$ \\
\hline
\end{tabular}


Berdasarkan analisis statistik dengan menggunakan chi - square diketahui nilai $\mathrm{p}<0,05$ artinya ada hubungan antara sikap dengan ketidak patuhan bidan praktik mandiri dalam penggunaan APD pada pertolongan persalinan normal. Dengan nilai RP sebesar 1,577 (95\% CI $=1,057-2,353)$ maka dapat disimpulkan bahwa bidan praktik mandiri yang memiliki sikap negatif 1,57 kali perkiraan resiko tidak patuh dalam penggunaan APD pada pertolongan persalinan normal.

Tabel 9. Hubungan Sarana Dengan Kepatuhan Penggunaan APD Oleh Bidan Pada Pertolongan Persalinan Normal Di Kota Tanjungbalai Tahun 2020

\begin{tabular}{ccccccccc}
\hline Saran & \multicolumn{4}{c}{ Kepatuhan Penggunaan } & \multicolumn{2}{c}{ Total } \\
$\quad$ APD & \multicolumn{2}{c}{ Tidak Patuh } & \multicolumn{2}{c}{ Patuh } & \multicolumn{2}{c}{ Proporsi } & p value & RP (95 \% CI) \\
& $\mathbf{n}$ & $\%$ & $\mathbf{n}$ & $\%$ & $\mathbf{n}$ & $\%$ & & \\
Tidak & 41 & 66,1 & 21 & 33,9 & 62 & 100 & 0,009 & 1,712 \\
Cukup & 17 & 38,6 & 27 & 61,4 & 44 & 100 & & $(1,133-2,586)$ \\
Cukup & 17 &
\end{tabular}

Berdasarkan analisis statistik dengan menggunakan chi - square diketahui nilai $p<0,05$ artinya ada hubungan antara sarana dengan ketidak patuhan bidan praktik mandiri dalam penggunaan APD pada pertolongan persalinan normal. Dengan nilai RP sebesar 1,712 (95\% CI $=1,133-2,586)$ maka dapat disimpulkan bahwa bidan praktik mandiri yang memiliki sikap negatif 1,71 kali perkiraan resiko tidak patuh dalam penggunaan APD pada pertolongan persalinan normal.

Tabel 10. Hubungan Penilaian Dengan Kepatuhan Penggunaan APD Oleh Bidan Pada Pertolongan Persalinan Normal Di Kota Tanjungbalai Tahun 2020

\begin{tabular}{ccccccccc}
\hline \multirow{2}{*}{$\begin{array}{c}\text { Penil } \\
\text { aian }\end{array}$} & \multicolumn{3}{c}{ Tidak Patuhan } & \multicolumn{2}{c}{ Patuh } & \multicolumn{2}{c}{ Total } \\
Proporsi & p value & RP (95 \% CI) \\
Tidak & $\mathbf{n}$ & $\mathbf{\%}$ & $\mathbf{n}$ & $\boldsymbol{\%}$ & $\mathbf{n}$ & $\boldsymbol{\%}$ & & \\
Ada & 19 & 37,3 & 32 & 62,7 & 51 & 100 & 0,001 & 1,903 \\
Ada & 39 & 70,9 & 16 & 29,1 & 55 & 100 & & $(1,283-2,823)$ \\
\hline
\end{tabular}

\section{Analisa Multivariat}

Analisis multivariat dilakukan untuk melihat beberapa variabel yang secara bersama - sama berhubungan dengan ketidak patuhan penggunaan APD oleh bidan pada pertolongan persalinan normal di kota Tanjungbalai tahun 2020. Pada penelitian ini dipergunakan uji regresi (multiple logistic regression) untuk mencari faktor yang paling dominan berhubungan dengan kepatuhan penggunaan APD oleh bidan pada pertolongan persalinan normal di kota Tanjungbalai tahun 2020. Adapun tahapan analisis multivariat sebagai berikut :

Tabel 11. Langkah Pertama Regresi Logistik Ganda Hubungan Pendidikan, Pengetahuan, Sikap, Sarana, dan Penilaian dengan Kepatuhan penggunaan APD Pada Pertolongan Persalinan Normal Tahun 2020

\begin{tabular}{lccccccc}
\hline \multicolumn{1}{c}{$\begin{array}{c}\text { Variabel } \\
\text { Independen }\end{array}$} & Wald & df & sig & RP & \multicolumn{2}{c}{$\begin{array}{c}\text { 95\% C.I for } \\
\text { RP }\end{array}$} \\
Pendidikan & 0,034 & 1 & 0,853 & 1,178 & 0,208 & 6,676 \\
Pengetahuan & 0,904 & 1 & 0,342 & 0,346 & 0,039 & 3,085 \\
Sikap & 0,606 & 1 & 0,436 & 0,364 & 0,028 & 4,645 \\
Sarana & 1,615 & 1 & 0,204 & 5,162 & 0,411 & 64,892 \\
Penilaian & 4,115 & 1 & 0,042 & 6,784 & 1,067 & 43,130 \\
Constan & 3,330 & 1 & 0,068 & 0,526 & & \\
\hline
\end{tabular}

Analisis multivariat bertujuan untuk mendapatkan variabel yang berhubungan paling dominan dengan ketidakpatuhan penggunaan APD oleh bidan pada pertolongan persalinan normal di kota Tanjungbalai tahun 2020 Dalam pemodelan ini semua kandidat di cobakan secara bersama - sama, kemudian variabel yang nilai $p>0,25$ akan dikeluarkan. Berdasarkan tabel 11 di atas dapat diketahui terdapat tiga variabel yang dikeluarkan dari analisis uji regresi logistik berganda karena mempunyai p > 0,25 yaitu pendidikan,pengetahuan dan sikap. Hasil analisis uji regresi logistik berganda menunjukkan bahwa variabel yang paling dominan adalah penilaian dengan nilai $R P=6,784$. Untuk lebih jelas dapat dilihat pada tabel 12 dibawah ini :

Tabel 12. Hasil Akhir Uji Regresi Logistik Ganda Hubungan Sarana Dan Penilaian Dengan Kepatuhan

Penggunaan APD Oleh Bidan Pada Pertolongan Persalinan Normal Kota Tanjungbalai Tahun 2020

\begin{tabular}{llllllll}
\hline $\begin{array}{l}\text { Variabel } \\
\text { Independen }\end{array}$ & B & S.E & $\begin{array}{l}\text { Wal } \\
\text { d }\end{array}$ & df & sig & RP & 95\% C.I for RP \\
\hline
\end{tabular}




\begin{tabular}{lllllllll}
\hline \multirow{3}{*}{ Penilaian } & 1,1 & 0,4 & 5,7 & 1 & 0,0 & 3,1 & 1,2 & 7,8 \\
& 32 & 74 & 03 & & 17 & 02 & 25 & 54 \\
Constan & 0,7 & 0,3 & 4,4 & 1 & 0,0 & 0,4 & & \\
& 07 & 34 & 76 & & 34 & 93 & & \\
\hline
\end{tabular}

Berdasarkan hasil analisis regresi logistik berganda tersebut diketahui faktor yang paling dominan berhubungan dengan kepatuhan penggunaan APD oleh bidan pada pertolongan persalinan normal di kota Tanjungbalai tahun 2020 adalah faktor penilaian dengan nilai $\mathrm{RP}=3,102$ sehingga dapat disimpulkan bahwa tidak ada penilaian pada bidan 3,10 kali lebih besar perkiraan kemungkinannya tidak patuh dalam penggunaan APD pada pertolongan persalinan normal dibandingkan dengan ada penilaian pada bidan.

\section{KESIMPULAN}

Berdasarkan hasil analisis dan pembahasan penelitian, maka dapat diambil kesimpulan Pada analisis bivariat variabel umur (faktor predisposing) tidak ada hubungan dengan kepatuhan penggunaan APD, sedangkan analisis bivariat pada variabel pendidikan, pengetahuan dan sikap (faktor predisposing) ada hubungan dengan kepatuhan penggunaan APD. Pada analisis bivariat variabel sarana (faktor enabling) terdapat ada hubungan dengan kepatuhan penggunaan APD. Pada analisis bivariat variabel penilaian (factor reinforcing) terdapat ada hubungan dengan kepatuhan penggunaan APD. Pada analisis multivariat dari variabel independen yang paling kuat hubungannya dengan kepatuhan penggunaan APD oleh bidan pada pertolongan persalinan normal adalah faktor reinforcing ( penilaian ). Sedangkan faktor predisposing dan faktor enabling tidak mempunyai hubungan yang signifikan terhadap kepatuhan penggunaan APD oleh bidan pada pertolongan persalinan nomal.

\section{REFERENSI}

Arikunto. 2006. Prosedur Penelitian Suatu Pendekatan Praktik. PT Rineka Cipta, Jakarta.

Azwar. 2010. Pengantar Administrasi Kesehatan edisi ketiga. Binarupa Aksara. Tangerang.

Azwar. 2010. Sikap Manusia Teori Dan Pengukurannya. Pustaka Pelajar. Yogjakarta.

Departemen Kesehatan RI, 1999, Himpunan Peraturan Perundang-undangan Bidang Kesehatan 1997-1998, Jakarta.

Departemen Kesehatan RI, 2008. Pelatihan Klinik Asuhan Persalinan Normal. Jakarta

Departemen Kesehatan RI, 2008. Keputusan Menteri Kesehatan RI No. 828/Memkes/SK/IX/2008.

Departemen Kesehatan R.I, 2010. Peraturan Menteri Tenaga Kerja dan Transmigrasi RINo.8/MEN/VII/2010.

Direktorat Bina Pelayanan Keperawatan dan Teknis Medik. Direktorat Jendral Bina Upaya Kesehatan Kementerian Kesehatan.2011. Keputusan Menteri Kesehatan RI No.1464/Menkes/Per/X/2010 Tentang Izin dan Penyelenggaraan Praktik Bidan.

Direktorat Bina Pelayanan Keperawatan dan Teknis Medik. Direktorat Jendral Bina Upaya Kesehatan Kementerian Kesehatan.2011. Keputusan Menteri Kesehatan RI No 369/Menkes/Sk/III/2007 Tentang Izin dan Penyelenggaraan Praktik Bidan

Direktorat pengawasan kesehatan kerja direktorat jenderal pembinaan pengawasan ketenaga kerjaan departemen tenaga kerja dan transmigrasi RI.

2005. PedomanbersamaILO /WHO. Jakarta

Direktorat Bina Kesehatan Kerja dan Olahraga, Direktorat Jendral Bina Gizi dan Kesehatan Ibu dan Anak Kementrian Kesehatan RI. 2011. Pedoman Keselamatan dan Kesehatan Kerja Puskesmas.

Direktorat Bina Kesehatan Kerja dan Olahraga, Direktorat Jendral Bina Gizi dan Kesehatan Ibu dan Anak Kementrian Kesehatan RI. 2011. Informasi Kesehatan Kerja. Jakarta.

Dinas Kesehatan Kabupaten Balangan.2010. Profil Dinasa Kesehatan Kaupaten Balangan 2010.

Dinas Kesehatan Kabupaten Balangan.2011. Profil Dinasa Kesehatan Kaupaten Balangan 2011.

Green W Lawrence.1980. Health Education Planning:Adiagnostic Approach. Mayfield Publishingcompany. California.

Hafidiyah. 2007. FaktorYang Berhubungan Dengan Tingkat Kepatuhan Perawat terhadap penggunaan APD di RSUD Pelabuhan Ratu Propinsi Jawa Barat. Skripsi Sarjana Kesehatan Masyarakat Universitas Indonesia.

Hastono. 2011. Analisa Data Kesehatan. Fakultas Kesehatan Masyarakat Universitas Indonesia.

Faktor-Faktor yang Berhubungan dengan Perilaku Perilaku Penggunaan Alat ... ( Evi Erianty Hasibuan) 
Jaringan Nasional Pelatihan Klinik(JNPK-KR)2007. Asuhan Persalinan Normal. Jakarta.

Kurniawidjaja,2007. Promosi kesehatan ditempat kerja.Direktorat Bina Kesehatan Kerja. Direktorat jendral bina kesehatan masyarakat. Departemen Kesehatan Masyarakat. Jakarta.

Laporan Hasil Riset Kesehatan Dasar (RISKESDAS) Nasional 2007 Badan Penelitian dan Pengembangan Kesehatan

Laporan Hasil Riset Kesehatan Dasar (RISKESDAS) Kalimantan Selatan 2007 Badan Penelitian dan Pengembangan Kesehatan.

Mansjoer, dkk. 1999. Kapita Selekta Kedokteran Edisi ketiga jilid I. Media Aesculapius. FKUI. Jakarta.

Mulyanti Dedek, 2008. Faktor predisposing, enabling dan reinforcing terhadap penggunaan alat pelindung diri dalam asuhan persalinan normal di rumah sakit Meuraxa Banda Aceh tahun 2008. Tesis Pascasarjana Universitas Sumatra Utara 2008.

MuninjayaGde. 2004Manajemen Kesehatan. EGC. Jakarta.

Notoatmdjo Soekidjo. 2010. Metodologi Penelitian Kesehatan. Rineka cipta. Jakarta.

Notoatmdjo Soekidjo.2005, Promosi KesehatanTeori dan Aplikasi, Rinekacipta. Jakarta.

Notoatmdjo Soekidjo. 2007. Kesekatan Masyarakat Umum dan Seni, Rineka cipta. Jakarta.

Notoatmdjo Soekidjo. 2007.Etika dan Hukum Kesehatan. Rineka cipta. Jakarta.

Ramli. 2010. Sistem Manajemen Keselamatan dan Kesehatan Kerja OHSAS 18001. Dian Rakyat. Jakarta

Sabri Luknis dan Sutanto Priyo Hastono. 2007. Statistik Kesehatan. PT Raja Grafindo Persada Jakarta.

Salamah dan Suyanto. 2008.Riset Kebidanan. Mitra Cendika Offset. Jogjakarta Sarwono.2010. Pengantar psikologi Umum. PT Raja grafindo Persada. Jakarta.

Samsudin.2006. Faktor-faktor yang berhubungan dengan tingkat kepatuhan penggunaan alat pelindung diri pada dokter gigi dan perawat gigi puskesmas di Kabupaten Purwakarta tahun 2006. Skripsi Program Sarjana Kesehatan Masyarakat Universitas Indonesia.

Silalahi B dan Silalahi NB, 1985.Manajemen Keselamatan Dan Kesehatan Kerja.

Seri Manajemen No11.IPPM, PT Pustaka Bina Pressendo dan PT Pertja. Jakarta.

Sitorus Ebtarina Melina.2011. Faktor-faktor yang berhubungan dengan perilaku penggunaan alat pelindung diri pada bidan desa saat melakukan pertolongan persalinan diwilayah kerja KabupatenToba Samosir tahun 2011. Skripsi Program Sarjana Kesehatan Masyarakat Universitas Indonesia.

Sugiyono.2009. Metode Penelitian Kuantatif Kualitatif dan R\&D. CV Alfabeta. Jakarta.

Tietjen, Bossemeyer, McIntosh. 2004. Panduan pencegahan infeksi untuk fasalitas pelayanan kesehatan dengan sumber daya terbatas. Yayasan Bina Pustaka Sarwono Prawirohardjo bekerjasama dengan JNPKKR/POGI dan JHPIEGO (Program MNH dan STARH).

TriastutiIda,2011. Persepsi bidan terhadap penggunaan alat pelindung diri yang lengkap pada saat melakukan pertolongan persalinan dikabupaten wonosobo tahun 2011. Skripsi Sarjana Kesehatan Masyarakat Universitas Indonesia.

Walgito Bimo. 2010. Pengantar Psikologi Umum. Andi. Yogyakarta

Walifah Elia. 2010. Faktor-faktor yang berhubungan dengan penggunaan APD pada pekerja didapur Unit Gizi RSPAD Gatot Soebroto Depkes tahun 2010. Skripsi Sarjana Kesehatan Masyarakat Universitas Indonesia.

Wawan dan Dewi.2010. Teori Dan Pengukuran Pengetahuan Sikap Dan Perilaku Manusia, Nuha Medika.Yogyakarta. 